\title{
THE PURPOSE OF LAW, PANCASILA AND LEGALITY ACCORDING TO ERNST UTRECHT: A CRITICAL REFLECTION
}

\author{
E. Fernando M. Manullang*
}

* Lecturer at the Faculty of Law Universitas Indonesia.

\section{Article Info}

Received : 2 April 2015 | Received in revised form : 29 June 2015 | Accepted : 27 July 2015

Corresponding author's e-mail : nando@ui.ac.id

\begin{abstract}
Ernst Utrecht is one of the best legal scholars Indonesia has ever had. His political views position him as an organic intellectual; a legal scholar involved in and expressing the social consciousness, both in the academic as well as in the political arena. His controversial involvement came to a tragic end, causing him to leave Indonesia for good. This article describes and reflects on some of Utrecht's rather controversial ideas about law and politics; namely, first, "pengayoman" (guardianship) the purpose of law in Indonesia, a purpose of law which is almost completely absent from the mainstream conception of the purpose of law in contemporary legal texts, as he relates it to the idea of revolution and the teaching of Marxism, albeit taking a more critical approach. Second, Pancasila as state ethics and grundnorm, a theme which remains debated up to the present time, in spite of Kelsen's express statement that grundnorm must be clean from non-legal elements, thus the implication of recognizing Pancasila as state ethics is that Pancasila as grundnorm loses its theoretical ground. Finally, the principle of legality, subject to Utrecht's strong critique for reflecting the interest of those in power only. All of his above described thinking undoubtedly reaffirm Utrecht's predicate as one of the best legal scholars Indonesia has ever had.
\end{abstract}

Keywords: the purpose of law, pengayoman, guardianship, Pancasila, grundnorm, the principle of legality.

\begin{abstract}
Abstrak
Ernst Utrecht adalah salah seorang sarjana hukum terbaik yang pernah dimiliki oleh Indonesia. Pandangan politiknya menempatkan dirinya sebagai seorang intelektual organik; sarjana hukum yang terlibat dan mengutarakan kesadaran umum yang ada di dalam masyarakat, baik itu di arena akademis, maupun di arena politis. Keterlibatannya yang kontroversial ini berakhir tragis, karena membuatnya meninggalkan Indonesia untuk selama-lamanya. Artikel ini memaparkan dan merefleksikan beberapa ide hukum dan politik Utrecht yang cukup kontroversial; yaitu, pertama, pengayoman sebagai tujuan hukum Indonesia, sebuah tujuan hukum yang nyaris tidak termasuk arus utama tujuan hukum dalam teks-teks hukum masa kini, karena ia merelevansikannya dengan ide revolusi dan ajaran Marxisme, namun dengan cara yang lebih kritis. Kedua, Pancasila sebagai etika kenegaraan dan grundnorm, tema yang terus menjadi perdebatan hingga masa kini, walaupun Kelsen jelas-jelas mengatakan bahwa grundnorm harus bersih dari unsur bukan hukum, dan oleh karenanya menerima Pancasila sebagai etika kenegaraan berimplikasi hilangnya dasar teoritis menerima Pancasila sebagai grundnorm. Yang terakhir mengenai asas legalitas, yang ia kritik secara keras, karena keberadaan asas tersebut hanya merefleksikan kepentingan kaum yang berkuasa. Pemikirannya ini semua tak pelak lagi mengokohkan predikatnya sebagai salah seorang sarjana hukum terbaik yang pernah dimiliki oleh Indonesia.
\end{abstract}

Kata Kunci: tujuan hukum, pengayoman, pancasila, grundnorm, asas legalitas. 


\section{Introduction}

Ernst Utrecht has been undoubtedly one of the best legal scholars in the early stage of Indonesia's post-independence days. He belongs to the first generation of authors writing about Indonesia's legal system in the post-independence era after Indonesia had gained its independence from Dutch colonialism. He embarked on such path by authoring the book being used as reference to this very day, at least from the historical aspect, namely, "Pengantar dalam Hukum Indonesia" ("An Introduction to Indonesian Law") which was first published in 1953 in Malang.

The predicate of his being the best was manifested when he became the first legal scholar cum lecturer to write a book about criminal law using the national language. As Utrecht himself stated, this was due to the fact that there were no actively teaching lecturers concurrently writing books about criminal law using bahasa Indonesia ${ }^{1}$ (the Indonesian language) at the time. His predicate of being the best became increasingly evident as he explored other areas of law, namely state administrative (constitutional) law and international law.

Unfortunately, parallel to President Soekarno's fall from political power, Utrecht experienced similar fate in the field of law in Indonesia. What was the causing factor? Up to the present time, there is no conclusive explanation available. However, it presumably occurred due to his views concerning law which were indeed in line with the political orientation of the government at the time. For the foregoing reasons, it is highly interesting to revisit Utrecht's ideas and reflect on the same, leading us to an understanding as to why it is befitting for the great name of Utrecht to be mentioned as one of the best legal scholars that Indonesia has ever had.

\section{Ernst Utrecht's Biography}

There are not many sources available in Indonesia about Ernst Utrecht, particularly about his life prior to graduating from law school. Based on the biography of his wife, Elien Utrecht, Ernst Utrecht was raised in the City of Malang and attended the Hogere Burgerschool (HBS) in that city. ${ }^{2}$ Before attending law school, Utrecht had enrolled at the Technische Hogeschool currently known as Institut Teknologi Bandung (ITB). His aspiration of becoming an engineer did not materialize due to the conditions of war. He was only able to continue his higher education after World War II, not in the field of technics, but in the field of law at Rijksuniversiteit Leiden. In 1951 he passed his doctoral exam ${ }^{3}$ in the field of Indonesian law at the said campus. ${ }^{4}$

1 See introduction to the book E. Utrecht, Hukum Pidana I: Suatu Pengantar Hukum Pidana untuk Tingkat Pelajaran Sarjana Muda Hukum, Suatu Pembahasan Pelajaran Umum [Criminal Law I: An Introduction to Criminal Law for Undergraduate Studies in Law, A General Discussion], p. 55. This book was probably published in 1958 based on information concerning the date in Utrecht's foreword.

2 Elien Utrecht, Melintasi Dua Jaman: Kenangan tentang Indonesia Sebelum dan Sesudah Kemerdekaan [Across Two Eras: Memories of Indonesia Before and After Independence], translated by Achmad Sunjayadi (Depok: Komunitas Bambu, 2006), p. 100.

3 This exam is equivalent to the title Sarjana Hukum (S.H.) of today, however the holder of sarjana hukum title at that time was qualified to undertake Strata 3 (S3) doctoral studies in law, which is different from sarjana hukum today.

${ }^{4}$ For this subject, refer to Elien Utrecht, Melintasi Dua Jaman [Across Two Eras], pp. 86-95, http://www. hukumonline.com/berita/baca/lt4f66e9aef0793/istudium-generale-i-mr-utrecht-di-unhas, accessed on 14 February 2014. 
Utrecht decided to become Indonesian citizen after The Netherlands ${ }^{5}$ had recognized Indonesia's sovereignty, and he returned to Indonesia on June 21, 1952. He then became instructor at the Kursus Dinas C (KDC) (C Service Course) of the Ministry of Home Affairs in Malang. He was lecturing on Introduction to the Science of Law and Administrative Law. ${ }^{6}$ Two years later, he became lecturer at the Faculty of Law of Universitas Indonesia. However, as lecturer of the Faculty of Law of Universitas Indonesia, he was assigned to Makassar and lectured on Introduction to the Science of Law. Due to such assignment, he had to travel frequently between Makassar and Jakarta. As there was a great lack of lecturers at the time, Utrecht was teaching in other cities as well, and in fact he became the co-founder of a university in the city of Ambon and of Universitas Sunan Gunung Jati in Cirebon. The said university in the city of Ambon had been initiated by a foundation, namely Yayasan Perguruan Tinggi Maluku. Rather than becoming a full-time lecturer in Jakarta, under Universitas Indonesia, in 1957 he decided to move to Bandung and to teach at Universitas Padjajaran ${ }^{7}$ During that period, Utrecht continued to teach actively in various cities, including Makassar, Ambon and Jember. ${ }^{8}$ He reached the peak of his structural position on campus when he was appointed as dean of the Faculty of Economics of Universitas Baperki. ${ }^{9}$

The reason for Utrecht moving to the city of Bandung, and ultimately leaving the Faculty of Law of Universitas Indonesia was due to a dispute that had arisen between him and a local military authority while in Ambon, Herman Pieters, who was also on the management board of the same university. As a result of the said dispute, on July 30,1960 Utrecht was dishonorably dismissed from the university. ${ }^{10}$

At Universitas Padjajaran, Utrechtlectured on criminal law replacing A. Astrawinata, $S . H$. , a part-time lecturer at the same faculty and the vice governor of West Java. ${ }^{11}$ During the said period, he authored two books on criminal law, with the title "Hukum Pidana I: Suatu Pengantar Hukum Pidana untuk Tingkat Pelajaran Sarjana Muda

\footnotetext{
${ }^{5}$ No conclusive source has been found so far to explain why Utrecht was a foreign citizen prior to that.

${ }^{6}$ He discussed the initial draft of this book with Prof. Resink. For this matter refer to Utrecht, op.cit., p. 109. On Prof. Resink, refer to E. Fernando M. Manullang (1), "Refleksi Terhadap Dilema G. J. Resink" ["A Reflection on G.J. Resink's Dilemma”] in “The Significance of the History of International Law in Indonesia," Jurnal Hukum Jentera Ed. 18 (January-June 2008).

${ }^{7}$ Based on information quoted from Hukum Online, in 1956 he decided to resign as civil servant (PNS) and to start a new profession as advocate in Jakarta, while lecturing at the Faculty of Law in Makassar, replacing mr. Dormeyer who returned to The Netherlands. In Makassar, Utrecht lectured on Introduction to the Science of Law at the preparatory level, and two other subjects, namely: The Principles of Criminal Law for undergraduate (sarjana muda) studies, and International Law at the graduate studies (sarjana). At the time, the Faculty of Law of Universitas Hasanuddin was still under the auspices of the Faculty of Law of Universitas Indonesia. Many of its lecturers were 'flying' (visiting) lecturers. In addition to mr. Utrecht himself, there were mr. Djokosoetono from Jakarta, mr. M. Kadaroesman from Surabaya, and mr. Moh. Koesno from Malang. This faculty of law was officially established on March 3, 1952 by virtue of Letter of the Minister of Education \& Culture No. No. 3399/Kab dated January 30,1952, the first leader of the Faculty of Law of Universitas Hasanuddin was Prof. Mr. Djokosoetono. This full-time senior lecturer of the Faculty of Law of Universitas Indonesia was subsequently replaced by Prof. Mr. C. de Heern, then by Prof. Drs. G.H.M. Riekerk. Hukum Online, "Studium Generale Mr. Utrecht di Unhas," http://www.hukumonline.com/berita/baca/lt4f66e9aef0793/istudium-generale-i-mr-utrecht-di-unhas, accessed on 14 February 2014.

${ }^{8}$ Utrecht, op.cit., p. 95.

${ }_{9}$ Ibid.p. 174.

${ }^{10}$ Ibid., pp. 146-147.

${ }^{11}$ It is also known that Utrecht was also a lecturer at the Faculty of Law in Ambon at the time, based on his own statement in his book: E. Utrecht, Hukum Pidana I and E. Utrecht, Hukum Pidana II: Suatu Pengantar Hukum Pidana untuk Tingkat Pelajaran Sarjana Muda Hukum, Suatu Pembahasan Pelajaran Umum [Criminal Law II: An Introduction to Criminal Law for Undergraduate Studies, A General Discussion].
} 
Hukum, Suatu Pembahasan Pelajaran Umum" ("Criminal Law I: An Introduction to Criminal Law for Undergraduate Studies in Law, A General Discussion") and "Hukum Pidana II: Suatu Pengantar Hukum Pidana untuk Tingkat Pelajaran Sarjana Muda Hukum, Suatu Pembahasan Pelajaran Umum" ("Criminal Law II: An Introduction to Criminal Law for Undergraduate Studies In Law, A General Discussion").

He wrote his book "Hukum Pidana I" ("Criminal Law I") while lecturing in Makassar from 1954 to 1956. The book was then published in 1958, and as he was promising in the preface to the book "Criminal Law I", the book "Criminal Law II" was going to be published in the same year. However, Utrecht was only able to make his promise a reality in 1960-1961; it was then that he wrote his book "Criminal Law II", and it was expected that the book would be published in about $1962 .{ }^{12}$ In addition to that, he also authored the book "Hukum Pidana: Rangkaian Sari Kuliah" ("Criminal Law: A Series of Lecture Summaries"). In addition to criminal law, he also wrote about international law, state administrative law, including the history of colonial politics.

Apart from being an expert in law and a lecturer, Utrecht was also known as a political party activist, namely of Partai Nasional Indonesia (PNI) (Indonesian National Party). He used to be the leader of the said party in Bali and apparently held leftist and revolutionary views on social classes. ${ }^{13}$ Therefore, while he was a PNI member, it may be inferred that from the ideological point of view he had a more revolutionary orientation compared to other PNI members, particularly those belonging to the rightoriented group under the leadership of Osa Maliki and Usep Ranawidjaja. This became quite obvious from Utrecht's statement to his wife saying that unless his party (PNI) became more militant, he would wish to move to Partai Komunis Indonesia (PKI) (Indonesian Communist Party). ${ }^{14}$ As a result of his political activities, he became one of the members of the Konstituante (Constitutent Assembly) Republik Indonesia,15 in addition to being appointed as member of the Supreme Advisory Council (Dewan Pertimbangan Agung (DPA)) at the end of July 1959. He was also elected as member of the Provisional People's Consultative Assembly (Majelis Permusyawaratan Rakyat Sementara (MPRS)) representing his party, PNI. ${ }^{16}$

He also took an extremely strong stance against militarism. As a result of this, along with his political views leaning to the extreme left, he frequently found himself in compromising situations, consequently facing various difficulties. The first of these difficulties emerged at the end of the 1950s. By that time, Utrecht had already taken an extremely critical stance against the military. Consequently, the unfortunate fate that he had experienced in Ambon served as a background for justifying his detention. ${ }^{17}$ The second incident occurred while he was lecturing in Jember. Utrecht

12 Excerpt from the foreword in E. Utrecht, Hukum Pidana I (Criminal Law I) and E. Utrecht, Hukum Pidana II (Criminal Law II).

${ }^{13}$ Geoffrey B. Robinson proposes Utrecht's social analysis of the Balinese community. In the said analysis Utrecht states that social classes as intended in the ideology of communism is not an important political factor in the Balinese community. Therefore, Utrecht concludes that Bali is not a fertile political ground for Partai Komunis Indonesia (PKI) (Indonesian Communist Party). See Geoffrey B. Robinson, "The Economic Foundations of Political Conflict in Bali, 1950 - 1965," Indonesia Volume 54 (1992).

14 This statement was triggered by Utrecht's disappointment over PNI's stance concerning the land reform. PNI chose to support land owners and to sabotage the land reform program. For this subject, refer to Utrecht, op.cit., p. 173.

${ }^{15}$ See Adnan Buyung Nasution, The Aspiration for Constitutional Government in Indonesia: A Socio-legal Study of the Indonesian Konstituante 1956-1959 (Jakarta: Pustaka Sinar Harapan, 1992), p. 304.

${ }^{16}$ Utrecht, op.cit., p. 138.

17 Ibid., p. 164. Elien tends to believe that Utrecht was detained for his anti-military stance. 
stated that there was a division between the state and the implementation of law vis-à-vis religion and the full and total comprehension of his faith. As a result of his statement, he was strongly condemned by by the public. ${ }^{18}$ And finally, on August 19, 1965 he was detained due to a political plot by the PKI faction while Utrecht was in Bali. Elien Utrecht, Utrecht's wife, suspected that the cause of Utrecht's detention was rivalry between political parties, namely PKI and PNI ${ }^{19}$ His detention continued following the September 1965 incident, and Utrecht was only released from detention on May $16,1966 .^{20}$

Following President Soekarno's fall, politics in Indonesia were not in favor of Utrecht's position. From 1968 to 1969, prior to leaving Indonesia for good, he was still working on a book concerning cremation in Bali, while gathering facts on the events of September 30 - October 1, 1965. Parallel to that, Utrecht was making endeavors towards leaving Indonesia. Ultimately, in 1969, he managed to leave Indonesia, without being accompanied by his wife and only daughter. He flew to Singapore for transit. While in Singapore, he was picked up by Harry Benda. ${ }^{21}$ Utrecht then flew to Australia under the pretext of following a lecture tour in Australia. ${ }^{22}$ While in Australia, Utrecht continued his lecture tour by taking up a full-time lecturer position at the University of Sydney, Australia. He was appointed as full-time senior lecturer in the field of third world development economics. He also became associate fellow at the Institute for Policy Studies/The Transnational Institute di Washington DC, United States. ${ }^{23}$ After Australia, he flew to Amsterdam, The Netherlands, and worked there with the recommendation of Prof. Wertheim. In The Netherlands, he continued to maintain the critical stance he had taken against the military of the New Order and President Soeharto during the lecture tour, as a result of which his wife and only daughter encountered extreme hardship in their endeavors to join him in The Netherlands. On September 30,1970 Elien Utrecht and their only daughter eventually managed to join Ernst Utrecht in The Netherlands, ${ }^{24}$ and they never came back to Indonesia as Indonesian citizens.25After leaving Indonesia, he did not continue to write about Indonesian law related issues; rather, he expanded his writings to the field of politics, the military and other areas.

18 Ibid., p. 200. Utrecht's name was written on walls added with the exclamation to hang him. Elien Utrecht accuses the group of Himpunan Mahasiswa Islam (HMI) (Islamic Students' Association) as the actors behind this act.

19 Ibid., p. 209. According to Elien Utrecht's statement, the leader of PKI in Bali at the time was a former PSI member who had been suspended by President Soekarno following the PRRI-Permesta Incident. Therefore, this act was only a show of vengeance.

20 Ibid., p. 225.

21 Harry Benda was an Indonesianist and a full-time senior lecturer in Southeast Asia Program, Yale University. He is the author of the classical book about the role of Indonesian muslims during Japanese occupation; The Crescent and The Rising Sun. He passed away at a young age on October 26, 1971. For this subject, refer to George McT. Kahin, "In Memoriam Harry J. Benda", http://www.yale.edu/seas/Benda_obit. pdf, accessed on 14 March 2015.

${ }^{22}$ Utrecht, op.cit., p. 233.

${ }^{23}$ Quoted from the foreword by Moh. Saleh Djindang in the book Pengantar Hukum Indonesia [An Introduction to Indonesian Law], 10th edition.

${ }^{24}$ Utrecht, op.cit., pp. 233-272.

25 Around the end of June and early July 1973, when his friend from Partai Nasional Indonesia (PNI) (Indonesian National Party) by the name of Bambang Kusnohadi passed away on June 27, 1973, Utrecht was in Jakarta, and offered his condolences to the deceased. Present on that occasion were several of his friends from various political factions such as John Lumingkewas, Kartjono (nationalists), Hardojo (communist) and others. See in Andrew H. Gunawan, "Honor to a Friend, Bambang Kusnohadi," Indonesia Volume 16 (1973): 149-152. 


\section{III.Discussion}

In a number of books written by him about Indonesian law, Utrecht proposes several rather interesting ideas which deserve further reflection. From the thematic point of view, these ideas can be classified into 3 themes, namely: his view on the purpose of Indonesian law, his reflection on Pancasila as grundnorm of the Indonesian nation, and finally, his view on the principle of legality. All of these three themes happen to be part of the book "Pengantar dalam Hukum Indonesia" ("An Introduction to Indonesian Law").

What is the reasoning behind the selection of these three themes? They offer a clear view of Utrecht's ideological stance with regards to the purpose of law within the Indonesian legal system, including his view on the existence of Pancasila within the legal system. Equally interesting is his ideological standpoint, positioning himself in an extremely critical stance vis-à-vis the principle of legality.

However, before reflecting on the above stated themes, there is a need for clarification first, in order to ensure that this reflection does not become biased due to intervention by Moh. Saleh Djindang, ${ }^{26}$ who has recently adapted Utrecht's work. For instance, Djindang has started adding colors to the book "Pengantar dalam Hukum Indonesia" ("An Introduction to Indonesian Law") in the 10th print, published in 1989. ${ }^{27}$ At the same time, Djindang started to become involved in the book "Pengantar Hukum Administrasi Negara Indonesia" ("An Introduction to Indonesian State Administrative Law") since $1985 .^{28}$ Unlike the books "Hukum Pidana I" ("Criminal Law I") and "Hukum Pidana II" ("Criminal Law II"), Djindang has had no contribution at all in the subsequent editions.29

In the preface to the book "Pengantar Hukum dalam Indonesia" ("An Introduction to Law in Indonesia") Djindang himself states that he was involved in the process of writing the book from the 4th print (1957) and the 5th print (1959) while Utrecht was still actively teaching in the city of Makassar. At the same time, Djindang makes a similar statement in the book "Pengantar Hukum Administrasi Negara Indonesia" ("An Introduction to Indonesian State Administrative Law"). Accordingly, since the 10th print of the book "Pengantar Hukum dalam Indonesia" ("An Introduction to Law in Indonesia") and the 8th print of the book "Pengantar Hukum Administrasi Negara Indonesia" ("An Introduction to Indonesian State Administrative Law"), the responsibility is already on Djindang's part. Consequently, the edition of "Pengantar Hukum dalam Indonesia" ("An Introduction to Law In Indonesia) and "Pengantar Hukum Administrasi Negara Indonesia" ("An Introduction to Indonesian State Administrative Law) used here can no longer be considered as Utrecht's authentic personal views, due to certain parts having been added, or potentially reduced, by

${ }^{26}$ Moh. Saleh Djindang was also known as an opinion leader in South Sulawesi. He co-founded the organization "Kerukunan Keluarga Sulawesi Selatan" (KKSS) ("Harmonious South Sulawesi Family") on November 12, 1976 di Jakarta. Other prominent figures involved included, among others, Manai Sophiaan, Andi Sose and Baharuddin Lopa. Downloaded from http://kkss-depok.blogspot.com/2013/03/sejarahsingkat-kkss.html on 8 February 2015.

${ }_{27}$ This book was first published in 1953, and continued to be republished up to 1966 in Jakarta (9th edition) in the name of Utrecht. However, starting 1983 (10th edition), the book was continued by Moh. Saleh Djindang.

${ }^{28}$ This book was first published in 1954, and continued to be republished up to 1964 ( 7 th edition) in the name of Utrecht. Following that, it was continued by Moh. Saleh Djindang.

${ }_{29}$ The book Hukum Pidana I dan II (Criminal Law I and II) presumably does not require any revision, as there have not been any changes in the Criminal Code (KUHP). 
Djindang for certain reasons unknown to us.30 Such exclusion is applicable only to the books "Hukum Pidana I" ("Criminal Law I") and "Hukum Pidana II" ("Criminal Law II").

Consequently, all historical facts stated after Djindang's involvement may be disregarded. Another consequence is that it is important to examine the above mentioned three themes in other books written by Utrecht, particularly in the field of criminal law, in order to distinguish the authentic from the non-authentic, or to identify the changes made by Djindang and the like.

\section{A. The Purpose of Law as Instrument of Pengayoman (Guardianship) and the Indonesian Revolution}

First of all, Utrecht describes several opinions about the purpose of law, such as to set order in a peaceful and fair society (van Apeldoorn); a purely ethical purpose namely justice (Aristotle); utilitarian purpose namely utility as a purpose of law (Bentham), in addition to utility, it should also be able of creating benefit and legal certainty (Bellefroid); the purpose of law is to maintain the interest of people in order to avoid disturbance (van Kan) and so on. ${ }^{31}$ And according to him, the purpose of law in the Indonesian legal system is the task of pengayoman (guardianship) within the realm of Pancasila. The reason for regarding pengayoman (guardianship) as the purpose of Indonesian law is because: 32

Alam yang berisi pandangan Bangsa Indonesia tentang negara sebagai suatu kebulatan yang hidup, sesuatu yang integral; yang tidak mengenal kontroverse antara Tuhan, Rakyat, Negara, Hukum. Rakyat ialah Rakyat bernegara berhukum dan ber-Tuhan. Setiap orang adalah makhluk kemasyarakatan. Alam yang memandang semua untuk semua, satu untuk semua, semua untuk satu, yang membentuk negara kebangsaan dan kesatuan tidak untuk suatu golongan kuat dan juga tidak bersandar pada suatu golongan yang kuat.

[A realm filled with the Indonesian Nation's view of the state as a living unity, something that is integral in nature; which does not recognize controversy between God, People, State, Law. The People are the People with a state, with a law and with a God. Every person is a social being. A realm which views all for all, one for all, all for one, forming a nation state and unity not for a single strong group, and not relying on a single strong group.]

Utrecht goes on to conclude that there is a realm of gotong royong (mutual cooperation) among all existing elements within the state, hence law as an instrument of pengayoman (guardianship) is also an instrument of the Indonesian Revolution. ${ }^{33}$

The purpose of law is to provide such guardianship, because according to Utrecht,

${ }^{30}$ Utrecht's wife stated, for instance, that Utrecht was extremely strict in drawing a line between the power of religion and state. He wrote about this in the first edition of the book Pengantar Dalam Hukum Indonesia [An Introduction to Indonesian Law]. For this subject, see Utrecht, op.cit., p. 201. However, in the 11 th edition of the same book (1989), it is actually stated that religion is capable of influencing law, in fact, it can become the law. For this subject see E. Utrecht and Moh. Saleh Djindang (1), Pengantar dalam Hukum Indonesia [An Introduction to Indonesian Law], 11th print, (Jakarta: Penerbit Ichtiar Baru and Penerbit Sinar Harapan, 1989), p. 6.

${ }^{31}$ Utrecht and Djindang, op.cit., pp. 11-14.

32 Ibid., p. 17.

33 Ibid. 
law is basically not an act of vengeance. Penance cannot be achieved through torture, such as imprisonment under criminal law. Hence, there is a need for guidance, apart from the criminal sanction which takes away freedom itself. There is a need for guardianship, rather than mere punishment. In other words, the purpose of criminal imprisonment is correctional in nature. This is what he refers to as pengayoman (guardianship) being the purpose of Indonesian law.

That being the case, what does he mean when he refers to law as an instrument of revolution? Utrecht states that, quoting Bung Karno, for understanding it one needs to refer first of all to the views of Karl Marx about law in a capitalist society. According to Marx, law is part of the superstructure. Thus, law is a reflection or imagination created by false consciousness, because the actual reality can be found only in economic relations, or production relations in society. ${ }^{34}$

Accordingly, in a capitalist society law is created for the purpose of maintaining capitalistic production relations, to maintain the existence and continuity of a certain order expected by the capitalist class controlling the tools of production. It is therefore Marx's proposition that law should reflect reality and it should eliminate such class contradiction. In such case, law is no longer present merely as an (ideological) consciousness; rather, it can stand as a reality itself. This is arguably the case because if it is merely an (ideological) consciousness, law consists of an argument or principle presumed to exist and to have been accepted in reality, thus causing law to be nothing more than a false consciousness. Therefore, law needs to be realigned to its underlying reality, consisting of arguments or principles that actually exist in society, rather than the interests of the capitalist group, free from the class contradiction in accordance with communist ideals, parallel to the disappearance of the state as an entity. In the context of such Marxist way of thinking, the law reflecting reality as described above can be used as an instrument of revolution.

Accordingly, Utrecht actually envisions a purpose of the law essentially evolving around the idea of an integralistic and harmonious organic state. The state providing guardianship in the field of law is the main idea of the purpose of Indonesian law, and law is capable of achieving such purpose if it is capable of serving as an instrument of the Indonesian Revolution which eliminates contradiction among the classes.

Utrecht's above described ideal is presumably based on his belief in the idea of a welfare state which can only be achieved if the state is based on the concept of mutual cooperation (gotong-royong). Public welfare will never be attainable if the state is based on Montesquieue's concept of trias politica concerning the separation of powers into several functions. In this regard, Utrecht tends to support Kelsen's idea stating that, for the purpose of public welfare, every state should be based on the distribution of powers, rather than the separation of powers. This is in view of the fact that each body within a state is capable of implementing more than one fuctions. ${ }^{35}$

At this point, it becomes highly evident that Utrecht is a Soekarnoist. He is proposing the idea of gotong royong put forward by Soekarno in the meeting of Badan Usaha-Usaha Penyelidik Kemerdekaan (BPUPK) (The Investigating Commitee for the Preparation of Independence) as the essence of the idea of Pancasila. ${ }^{36}$ By

\footnotetext{
${ }^{34}$ Ibid., pp. 17-20.

${ }^{35}$ E. Utrecht and Moh. Saleh Djindang (2), Pengantar Hukum Administrasi Negara Indonesia, [An Introduction to Indonesian State Administrative Law], 8th ed., (Jakarta: Ichtiar Baru, 1985), p. 15.

${ }^{36}$ For Soekarno's speech about Pancasila and gotong royong, see Saafroedin Bahar, Ananda B. Kusuma and Nannie Hudawati, Risalah Sidang Badan Penyelidik Usaha-Usaha Persiapan Kemerdekaan Indonesia
} 
doing so, he positions himself on the same side as Professor Soepomo, regarding the Indonesian state as an integral unity, devoid of contradictions among groups. ${ }^{37}$ He also demonstrates the same understanding of revolution as Soekarno's marxian understanding of revolution; however, quite remarkably, Utrecht does not make any mention at all of the difference in social analysis between Karl Marx and Marhaenism, Soekarno's teaching of marxian nature, which has served as the ideological basis of Utrecht's party, namely PNI. ${ }^{38}$

\section{B. Pancasila as State Ethics and Grundnorm}

Speaking of the idea of guardianship, according to Utrecht it is inseparable from Pancasila. ${ }^{39}$ In Utrecht's view, Pancasila itself is a state principle and it is the grundnorm for laws and regulations in Indonesia. Furthermore, Utrecht states that Pancasila first came into existence in the hands of Bung Karno, on June 1, 1945 in front of Badan Penyelidik Persiapan Usaha-Usaha Kemerdekaan (the Investigating Committee for the Preparation of Independence). Soekarno stated that Pancasila is the five-pillar philosophical foundation (philosofische grondslag) or weltanschauung of the Indonesian state, which serves as the driving force and basis of the Indonesian people as Indonesian citizens. ${ }^{40}$ Utrecht goes on to quote the view of Prof. Notonagoro stating that Pancasila is a fundamental state norm (staatsfundamentalnorm), or it can also be referred to as positive morality, as it contains state ethics set out in the Preamble to the Constitution. ${ }^{41}$

The presentation of the above described ideas by Utrecht, as one of PNI's exponents, can be considered as being descriptive-formal in nature. He is positioning Pancasila merely as a historical image formalized as state ethics. By doing so, Utrecht totally refrains Pancasila from an ideological point of view. At the same time, his own party, PNI, was making assertive endeavors towards projecting the idea of Pancasila in an ideological manner with the teaching of Marhaenism..$^{42}$ At this point, Utrecht's character as a positivist legal scholar comes through very strongly, as he views

(BPUPKI) - Panitia Persiapan Kemerdekaan Indonesia (PPKI) [Proceedings of the Session of The Investigating Committee for the Preparation of Indonesian Independence - Preparatory Committee for Indonesian Independence] (Jakarta: Sekretariat Negara Republik Indonesia, 1995), pp. 63-84.

${ }^{37}$ Marsillam Simanjuntak, Pandangan Negara Integralistik: Sumber, Unsur, dan Riwayatnya dalam Persiapan UUD 1945 [An Integralistic View of the State: Its Sources, Elements and History in the Preparation of the 1945 Constitution] (Jakarta: Pustaka Utama Grafiti, 1994), p. 82.

38 For the teaching of Marhaenism, see Sukarno, "Marhaen, A Symbol of the Power of the Indonesian People," in Indonesian Political Thinking 1945-1965, edited by Herber Feith and Lance Castles, (Jakarta: Equinox Publishing, 2007), pp. 154-160.

${ }^{39}$ Utrecht and Djindang (1), op.cit., p. 84.

40 Ibid., pp. 83-84.

${ }^{41}$ Ibid., p. 84. M. Sastrapratedja's statement about Pancasila as political ethics which contains "cultural software". See M. Sastrapratedja, "Pancasila Sebagai Dasar Negara, Asas Etika Politik dan Acuan Kritik Ideologi" ["Pancasila As Foundation of the State, the Principle of Political Ethics and Reference in Ideological Critique"] in Proceeding Kongres Pancasila: Pancasila Dalam Berbagai Perspektif [Pancasila Congress: Pancasila In Various Perspectives], edited by Moh. Mahfud MD et. al. (Jakarta: Sekretariat Jenderal Mahkamah Konstitusi, 2009), pp. 65-73.

${ }^{42}$ See J. Elisio Rocamora, Nasionalisme Mencari Ideologi: Bangkit dan Runtuhnya PNI, 1946-1965 [Nationalism in Search of Ideology: The Rise and Fall of the Indonesian Nationalist Party, 1946-1965], translated by Daniel Dhakidae, (Jakarta: Pustaka Utama Grafiti, 1991), p. 108. See also E. Fernando M. Manullang (2), "Negara dan Pancasila: Refleksi Kritis Atas Gagasan Hukum Padmo Wahjono," ["The State and Pancasila: A Critical Reflection On the Legal Ideas of Padmo Wahjono"], Jurnal Hukum Jentera Ed. 15, Year IV (January-March 2007). 
Pancasila merely in a formal way, while avoiding the ideological debate. ${ }^{43}$

This is indeed a crucial issue, considering that Pancasila as an ethical idea must first be examined against a basic need, namely whether it contains a programmatic idea, in order to answer whether or not Pancasila can be classified as an ideology. By doing so, is it to be expected that the endeavor of the marhaenist group within $\mathrm{PNI}^{44}$ to treat Pancasila as an ideology would result in endeavors to position Pancasila within the the leftist paradigm, considering that the discourse on ideology, as stated by Roger Eatwell, is embedded in a leftist tradition ${ }^{? 45}$

Rather than joining the efforts to place Pancasila as a leftist ideology, Utrecht follows in the footsteps of Prof. Notonegoro who regards Pancasila as state ethics. However, at the same time Utrecht creates another issue by concurrently positioning Pancasila as grundnorm. Why so? Because grundnorm, as a term defined by Hans Kelsen, continues to create polemics concerning the meaning of the term grundnorm itself.

Kelsen states that grundnorm exists because the hierarchy of legal norms must end in the norm of the highest rank, and such norm serves as a basis for the validity of all legal norms under it. Accordingly, Kelsen states that the above mentioned highest norm:46

[...] as the last and the highest, is presupposed. It must be presupposed, because it cannot be "posited", that is to say: created, by an authority whose competence would have to rest on a still higher norm. The final norm's validity cannot be derived from a higher norm, the reason for its validity cannot be questioned. Such a presupposed highest norm is referred to in this book as basic norm. ${ }^{47}$

If the grundnorm is presupposed, the question arises: how is such grundnorm presupposed? This is a logical question, considering that grundnorm is not the equivalent of "God". Grundnorm does not appear all of a sudden as the beginning and the end of all existing norms, regardless of time and place, because the grundnorm is always related to the national order of norms ${ }^{48}$ thus creating the need for a "genesis" of all norms which exist in the national order of norms.

43 Ibid.

44 The aim of Marhaenism is to create a marhaenist community sharing feelings and happiness, in which no single individual or group oppresses another individual or group. Members of the marhaenist community work together and help each other for the interest of the state. For the political views of PNI (December 1952) refer to Herbert Feith and Lance Castles, Indonesian Political Thinking 1945-1965 (Jakarta: Equinoxx Publishing, 2007), pp. 160-164.

45 Roger Eatwell, "Ideologies: Approaches and Trends," in Contemporary Political Ideologies, edited by Roger Eatwell and Anthony Wright (Boulder, San Fransisco: Westview Press, 1993), p. 1-22. See also E. Fernando M. Manullang (2), op.cit., pp. 134-155. Soerjanto Poespowardojo refuses to position Pancasila within the leftist paradigm, because according to him, Pancasila is an ideology oriented towards unity, and development, and as such it is open. See in Soerjanto Poespowardojo, "Pancasila Sebagai Ideologi Ditinjau Dari Segi Pandangan Hidup Bersama" ["Pancasila As An Ideology Viewed from the Aspect of Living In A Community"], in Pancasila Sebagai Ideologi dalam Berbagai Bidang Kehidupan Bermasyarakat, Berbangsa dan Bernegara [Pancasila As Ideology in Various Areas of Life As Society, Nation and State], edited by Oetojo Oesman and Alfian, (Jakarta: BP-7 Pusat, 1991), pp. 44-61.

${ }^{46}$ Hans Kelsen, The Pure Theory of Law (California: University of California Press, 1967), pp. 193-194.

${ }^{47}$ Ibid., pp. 194-195.

48 Ibid., p. 199. However, on the other hand, Kelsen also states that grundnorm in the national system of norms is also related to the system of norms of international law, and quite uniquely, he positions the relationship between the national and international system of norms as a hierarchical relation. See also Kelsen, op.cit., p. 214. 
Kelsen's answer to the above question is that: ${ }^{49}$

[...] it refers directly to a specific constitution, actually established by the custom or statutory creation, by and large effective, and indirectly to the coercive order created according to this consitution and by and large effective.

That being the case, Kelsen relates the grundnorm to the constitution. This potentially raises a problematic question from the academic point of view namely, supposing that the grundnorm can be found in a certain constitution -and according to Kelsen it can be found in the first constitution- and it serves as a normative umbrella for all norms that exist in a certain order of positive legal norms, as Marsillam Simanjuntak puts the question, how is it possible for Pancasila, if it is considered as grundnorm, to serve as grundnorm for 3 constitutions (the 1945 Constitution, the 1949 RIS Constitution, and the 1950 Provisional Constitution) which used to be applicable in Indonesia? Could it imply that Pancasila as grundnorm possesses such a high level of flexibility that it was capable of being used for three different constitutions ${ }^{50}$

Marsillam Simanjutak's above mentioned critical claim deserves attention due to the practical complication it unavoidably raises. Kelsen's statement that grundnorm is presupposed implies that grundnorm is a "meta-legal" juridicial idea. ${ }^{51}$ Based on such understanding, Kelsen goes on to say that "The presupposition of the basic norm does not approve any value transcending positive law," ${ }^{\prime 52}$ thus positioning the grundnorm not only outside the existing legal system, but also as being unrelated, as a value, to the existing values in the legal system. In other words, the grundnorm does not endorse in any manner whatsoever values such as justice or peace which can be found in the constitution or certain legislation. Based on such understanding, if Pancasila is considered as grundnorm, it cannot be claimed that Pancasila endorses the value of justice in the 1945 Constitution, a statement that would be certainly rejected by A. Hamid S. Attamimi for instance, because according to Attamimi, matters set out in the body of the 1945 Constitution are a reflection of the values of Pancasila. ${ }^{53}$

Such practical complication occurs because Kelsen does not offer a distinct explanation as to what he means by grundnorm. This is due to the fact that from the very outset he positions grundnorm as part of his idea of the Pure Theory of Law, which attempts to provide a methodological explanation as to what the law is, eliminating all non-legal elements. ${ }^{54}$ The purpose of the existence of grundnorm as part of his endeavors to explain the hierarchy of norms is in fact to identify a unit of the legal system. ${ }^{55}$ Accordingly, from the outset Kelsen does not have any ideological intentions related to the grundnorm.

Therefore, related to Kelsen's thinking, Utrecht's statement that "Pancasila is the

${ }^{49}$ Kelsen, op.cit., p. 201.

50 Simanjuntak, op.cit., p. 24.

51 M. D. A. Freeman, Llyod's Introduction to Jurisprudence, 6th edition, (London: Sweet \& Maxwell Ltd., 1994), p. 282.

${ }^{52}$ Kelsen, op.cit., p. 201

${ }^{53}$ A. Hamid S. Attamimi, "Peranan Keputusan Presiden Republik Indonesia Dalam Penyelenggaraan Pemerintahan Negara: Suatu Studi Analisis Mengenai Keputusan Presiden Yang Berfungsi Pengaturan Dalam Kurun Waktu Pelita I - Pelita IV" ["The Role of the Decree of the President of the Republic of Indonesia In State Administration: A Study on the Analysis of Presidential Decree Functioning as Regulation During the Period of Ist Five Year Development Plan"], (Dissertation to Attain the Title Doktor Dalam Ilmu Hukum, Universitas Indonesia, Jakarta, 12 December 1990), p. 360.

${ }^{54}$ Kelsen, op.cit., p. 1.

${ }^{55}$ Freeman, op.cit., p. 283. 
grundnorm for laws and regulations in Indonesia" may be considered as a hastily made statement. The ideological content, in particular, has never been part of the methodological basis of Kelsen's Pure Theory of Law. Similarly, relating to Pancasila manifested in the Preamble as grundnorm -because Utrecht refers to Pancasila as grundnorm for laws and regulations in Indonesia- is also a hastily made statement, if the grundnorm he refers to is Hans Kelsen's grundnorm.

This is because Kelsen makes it clear in his statement that the grundnorm can be found in the constitution, however, constitution not in the sense of positive law, but constitution in the legal-logical sense, which can be found in the historically first constitution, ${ }^{56}$ which is the 1945 Constitution in the Indonesian context. However, if that is the case, as stated by Marsillam Simanjuntak, how is it possible for the grundnorm which exists in the constitution in the above mentioned legal-logical sense to provide the hierarchy of norms under the other 2 constitutions (the 1949 RIS Constitution and the 1950 Provisional Constitution)?

Utrecht's proposal about state ethics and grundnorm undoubtedly raises a critical issue due to the fact that on the one hand, he recognizes Pancasila as ethics in the context of a state, while on the other hand Kelsen explicitly rejects the interpretation of such grundnorm as state ethics. Kelsen's statement leaves no doubt that his theory is devoid of non-legal nuances, including ethics.

\section{The principle of legality}

Utrecht critically attacks the principle of legality set out in Article 1 paragraph 1 of the Criminal Code. The principle which is also known by the adagium: nullum delictum, nulla poena sine praevia lege poenali, has been the result of adopting the spirit of protecting individual freedom as set out in the idea of trias politica proposed by Montesquieu in his book L'Esprit des Lois (1748). Montesquieu's idea is aimed at protecting the interest of the individual against arbitrary judiciary treatment, which was a generally prevailing reality in Europe before the French Revolution. The said idea was further promoted and became manifested in Article 8 of Declaration du droit de'l homme et du citoyen (August 26, 1789), and also Article 4 of the French Code Penal. ${ }^{57}$

Utrechtgoes on to explain that the adagium: nullum delictum or the legality principle was in fact created by a legal scholar by the name of Anselm von Feuerbach (17751833) in his book Lehrbuch des peinliches Recht (1801). The said adagium was created with the expectation that the human desire to do evil can be curbed or prevented with explicit threat of punishment set forth in the criminal code. Thus, von Feuerbach is providing for psychological prevention (psychologische zwang) ${ }^{58}$ Accordingly, despite similarities in their basic ideas, there are still differences between Montesquieu and von Feuerbach. While Montesquieu's intention is to provide protection to the human being against arbitrary judiciary treatment, von Feuerbach purports to limit the human psychological desire to do evil.

Even though Utrecht recognizes the legality principle as a constitutional principle, which means that it cannot be set aside, he states several objections. First, this principle does not protect the collective interest (of the community). This is due to the fact that

\footnotetext{
${ }^{56}$ Ibid., p. 284.

57 Utrecht and Djindang (1), op.cit., pp. 388-389.

58 Ibid., p. 389.
} 
certain people can commit punishable acts (strafwaardig), even though such acts are not yet provided for in the criminal code. Second, this principle is individualistic in nature due to its origins, and a logical consequence, every effort to provide collective protection is bound to be ignored due to the existence of this principle. ${ }^{59}$ Third, this principle ultimately leads to the non-implementation of customary criminal law, while in fact there was still a rather strong influence of customary criminal law in the decisions of criminal judges at the time..$^{60}$

Fourth, the existence of unwritten law should not be used as a reason to state that a state has experienced deterioriation. Several Western countries, such as the United Kingdom and the United States of America are still applying unwritten criminal law. And finally, fifth, the aim of codification is accordingly not to create legal certainty, but rather to provide protection to the ruling class in society, as they are in a position to determine, or to formulate, whether or not a certain act is considered as a criminal act. $^{61}$

Utrecht's rejection of legality is a highly interesting subject for discussion, particularly in the part where he rejects legality due to its individualistic nature. The argument behind such rejection is that the legality principle does not provide protection for the public (collective) interest. The issue that arises is that Utrecht's rejection is not comprehensive, and neither can it be considered as accurate, although it is not entirely mistaken. Why so? Because the historical background of legality is inseparable from the idea of legism. ${ }^{62}$

What is legism itself? Legism is a legal school of thought which reached its golden age in the 19th century in Europe, stating that the implementation of law is strictly limited to the implementation of the provisions of the law considering that law is a logical system and it can be applied in all concrete cases. ${ }^{63}$ Therefore, judges function only as the "mouth that pronounces the words of the law" ${ }^{64}$ Such function has been adopted from Montesquieu's ideas in his above mentioned book. ${ }^{65}$ Thus, Montesquieu attributes a special role to the judicative branch of power, rather than merely describing the existing branches of power in a state (trias politica), as stated by Rousseau. In other words, Rousseau describes the structure of power in a very

${ }^{59}$ E. Utrecht, Hukum Pidana I [Criminal Law I], pp. 195-197.

60 This was reinforced in E. Utrecht's article, "Hukum Pidana jang tidak Tertulis (Ongeschereven Strafrecht)" ["Unwritten Criminal Law"], in Buku Peringatan Dies Natalis Ke-VI Senaat Mahasiswa Fakultas Hukum dan Pengetahuan Masjarakat Universitas Indonesia [Year Book Dies Natalis VI of the Students' Senate of the Faculty of Law and Social Science Universitas Indonesia], (Jakarta: Senaat Mahasiswa Fakultas Hukum dan Pengetahuan Masjarakat Universitas Indonesia, 1956), p. 52 et seqq.

61 Ibid., p. 198-201.

${ }^{62}$ See for instance L. J. van Apeldoorn, Inleiding tot de Studie van het Nederlandse Recht, atau Pengantar Ilmu Hukum [Inleiding tot de Studie van het Nederlandse Recht, or An Introduction to the Science of Law], 23rd print, translated by Oetarid Sadino, (Jakarta: Pradnya Paramita, 1986), pp. 133- 134.

${ }^{63}$ Ibid., p. 133. Compare with Theo Huijbers, Filsafat Hukum [The Philosophy of Law], 3rd print, (Yogyakarta: Penerbit Kanisius, 1995), p. 121.

64 Ibid., p. 121.

${ }^{65}$ Charles de Secondat Baron de Montesquieu, The Spirit of Laws (New York: Prometheus Books, 2002), p. 75. See Satochid Kartanegara, Hukum Pidana: Kumpulan Kuliah [Criminal Law: A Collection of Lectures], pp. 179-181; See also Jan Remmelink, Hukum Pidana: Komentar atas Pasal- Pasal Terpenting dari Kitab Undang-Undang Hukum Pidana dan Padanannya dalam Kitab Undang- Undang Hukum Pidana Indonesia [Criminal Law: Commentary on the Most Important Articles of the Criminal Law and Concordance with the Indonesian Criminal Code], translated by Tristam Pascal Moeliono, et al., (Jakarta: Gramedia Pustaka Utama, 2003), pp. 44-45; See also R. Soesilo, Pokok-Pokok Hukum Pidana, Peraturan Umum dan Delik- Delik Khusus [Fundamentals of Criminal Law, General Provisions and Special Offense] (Bogor: Politea, 1984), p. 41. 
similar manner to Montesquieu, however, unlike Montesquieu, Rousseau does not place any specific emphasis on the role of judges. ${ }^{66}$

Notwithstanding the difference between Rousseau and Montesquieu, they both share the same idea about the structure of power in a state. It is not surprising, therefore, that jurists tend to draw the golden thread between Rousseau and Montesqueiu holding the view that both of them have laid the foundations for the idea of legism. ${ }^{67}$ It is in such context that the golden thread of legality, too, is established. Judges act only as the "mouth" of the law, preventing them from pronouncing judgment for any criminal acts which are not stated as criminal acts in the criminal code. In other words, judges are the mouth in matters set forth legalistically in the criminal code. Utrecht fails to recognize Montesqueieu's role in cases of legism as well as legality, considering that Montesquieu is not only the main conceptor in the thought about legality; he is also the main founder of the idea of legism, together with Rousseau. ${ }^{68}$

Utrecht's failure to recognize this becomes increasingly evident in his statement that legality is a principle which, due to its individualistic nature, does not prioritize collective interest. Indeed, considering that legality is derived from legism, while legism has been nurtured not only by Montesquieu, but also by Rousseau, the individualistic character becomes quite prominent in the principle of legality. Such individualistic character appears in Rousseau's philosophical treaty, The Social Contract, in which Rousseau starts by explaining how the individual becomes an essential existence in the life of society and state. Therefore, Rousseau reminds that the existing law (legislation) is a reflection of the political aspiration of individuals living in association within a state. The power mandated by such individuals is expected to be able to stipulate law (legislation) which is in accordance with such political aspiration. Consequently, if the law (legislation) stipulated by the said power is contradictory to the public will, Rousseau advises each of these individuals to reject it. $^{69}$

${ }^{66}$ Rousseau actually states that the judiciary should be ad hoc (rather than permanent), because he does not wish to see the creation of a new "tyranny" outside the government and the legislature, which can overcome other branches of power. Jean-Jacques Rousseau, The Social Contract (London: Penguin Books, 1968), pp. 169-170.

67 See Apeldoorn, op.cit., pp. 133- 134. See also J. M. van Bemmelen, Ons Strafrecht 1: Het materiele strafrecht algemen deel [Criminal Law 1: Criminal Law Material General Part], translated by Hasnan (Bandung: Binacipta, 1987), pp. 49-53. See Machteld Boot, Nullum Crimen Sine Lege and the Subject Matter Jurisdiction of the International Criminal Court: Genocide, Crimes Against Humanity, War Crimes, (School of Human Rights Series, Volume 12) (Antwerpen: Intersentia), p. 83.

${ }^{68}$ In addition to the above mentioned three philosophers, there are some other philosophers who have clearly contributed to developing the methods of legality, and were subsequently adopted by Johann Anselm von Feuerbach (1755-1833) in the Criminal Code of Bavaria (1813); namely Cesare Beccaria. Beccaria explicitly states in his book Dei delliti e delle pene (1764) that the criminal code may not be interpreted by judges, as judges are neither legislators, nor the representatives of the people. Only legislators are able to determine what is and what is not punishable. For this subject, see Cesare Beccaria, Of Crimes and Punishment (New York: Marsilio Publishers, 1996), pp. 14-15. For von Feuerbach's role, see Arthur T. von Mehern, "Paul Johan Anselm von Feurbach," in Encylopedia Americana Volume 11 (Connecticut: Grolier Incorporated, 1983), pp. 143-144.

${ }^{69}$ Mads Qvortrup, The Political Philosophy of Jean-Jacques Rousseau: The Impossibility of Reason (Manchester: Manchester University Press, 2003), p. 60. John Locke, one of the philosophers who have laid the ground for the Theory of Social Contracts, actually suggests engaging in revolt or rebellion. For this subject, see Frederick Copleston, A History of Philosophy Volume V: Modern Philosophy: The British Philosophers from Hobbes to Hume (New York: Doubleday, 1959), p. 138. 
By doing so, Rousseau does not deny the existence of public will, or in Utrecht's words referred to as collective interest. Rousseau does not see a binary opposition relationship between individual interest and collective interest. As a matter of fact, he holds that individuals must be encouraged towards and should encourage the collective will if their collective interests are violated by those in power. At the same time, Montesquieu himself, as stated earlier, does not at all deal with the issue of individual or public (collective) interest in his above mentioned book. This is the point at which Utrecht's omission becomes obvious, as he presumes that the legality proposed by Montesquieu and von Feuerbach is aimed at protecting individual interest rather than collective interest. While in fact, by accepting the idea that legality is derived from legism, it is not entirely correct to state that the sole purpose of legality is to protect individual interest, as Rousseau himself encourages every individual to fight for their public will, if such public will is violated by those in power. Such is the essence of the idea of legality which is founded on legism.

However, despite Utrecht's omission particularly in viewing Montesqueiu's role, there are several interesting critical notes by Utrecht related to legality. This is notably his critical attack stating that the actual objective of codification is to protect the ruling class, including the claim related to codification providing legal certainty. ${ }^{70}$ Such critique is also launched by Critical Legal Studies holding the view that legal doctrines set out in the laws (code), including studies at law schools are aimed at preserving certain ideological interests of the ruling class. ${ }^{71}$ Rather than calling on jurists to reinterpret the critique launched by Critical Legal Studies, Utrecht reminds of the existence of uncodified customary criminal law, considering that in his view, the influence of customs and traditions on law cannot be just simply ignored. ${ }^{72}$

\section{Critical Reflection}

Utrecht undoubtedly deserves to be regarded as one of the best legal scholars Indonesia has ever had. This is due to the fact that he is part of the early generation which attempted to translate Indonesia's revolutionary legal politics of their time. He also belongs to the early generation of scholars striving to engage in scientific argumentation from the perspective of legal science concerning the position of Pancasila in the constitution and Indonesia's legal system. Most significantly, he demonstrated courage in critically rejecting the Western concept of legality and codification, and in supporting customary criminal law. His intellectual proposals are truly visionary, particularly in the area of customary criminal law, which currently tends to be overlooked, although its implementation remains as relevant as ever ${ }^{73}$

${ }^{70}$ According to Karl Llewellyn mathematical certainty is not the essence of law. In fact, uncertainty is not necessarily incorrect; rather, it is a value of excellence in law. There are several reasons supporting this argument: (1) law is like a porous structure, whereby judges have discretion in implementing it, (2) law should be sharpened with moral considerations, otherwise law becomes a composition of rules which may potentially become irrelevant in certain situations, (3) law made by the legislature is not always identical to the law as perceived by the judicature, (4) law should be ideally subject to constant reform, and finally, (5) law, particularly judicial decisions, must be subject to constant review vis-à-vis the values of life wisdom, in order to ensure that law becomes more meaningful. For this subject, see Suri Ratnapala, Jurisprudence (Cambridge: Cambridge University Press, 2009), pp. 102-105.

${ }^{71}$ They are usually the ruling class with liberal ideology. For this subject, see in Mark Tebbit, Philosophy of Law: An Introduction (London: Routledge, 2005), pp. 79-80.

${ }^{72}$ See E. Utrecht and Moh. Saleh Djindang (1), op.cit., pp.4-8.

${ }^{73}$ Bernadinus Steni, "Hukum Progresif, Pluralisme Hukum dan Gerakan Masyarakat Adat," ["Progressive 
because, in Utrecht's perspective, punishment under customary criminal law is not retributive in nature.

Notwithstanding his minor omission in viewing Pancasila as grundnorm after relating it to state ethics, including his statement on the individualistic nature of legality derived from Montesquieu's philosophy, his nationalistic leftist political view reaffirms that -using Antonio Gramsci's philosophical reflection- he is an organic intellectual taking sides with social interest, unlike traditional intellectuals who tend to keep apart from the objective of struggle. ${ }^{74}$ This becomes quite evident at the point where Utrecht deals with legal issues demonstrating psychological involvement with society and expressing contemporary political feelings and sentiments, particularly the voice of customary law community. He also offers an ideological view concerning the objective of law in Indonesia. In this respect, he is positionally opposed to Kelsen who is extremely normative, even though he takes over Kelsen's term grundnorm to explain his view of the position of Pancasila. Briefly, he is a legal scholar with a certain ideology.

His orientation towards ideology is an important note for the generation of legal scholars of today, who tend to be impressed by the claim of objectivity and neutrality of positive legal science. It may well be stated that -as an organic intellectual- he is a legal scholar positioning himself just like Critical Legal Studies, which suspects every legal science of positivist and formal character, looking at the claims of such science for objective and neutral answers in order to provide legal certainty. ${ }^{75}$ However, unlike Critical Legal Studies which offer critical methods for understanding law, Utrecht takes a more radical view of legal issues in Indonesia, choosing to take sides ideologically, rather than proposing critical interpretation as done by Critical Legal Studies. Regardless of whether or not he took the incorrect sides, the important thing is that Utrecht indirectly reminds all of us that the science of law is never neutral, let alone objective. It raises issues of power, making law in a certain way, depending on the holders of power.

In this respect, Utrecht demonstrates inconsistency. As part of PNI, he may be considered as the "mouth" of leftist legal politics in the ranks of law school. Such role positions Utrecht as instrument of the ruling class in power at the time. At the same time, he is taking sides with the people, particularly customary law communities, although epistemologically, being the "mouth" of law school is not a despicable or mistaken position for a legal scholar, considering that the structure of the science of law is present in the existing legal system. It is not outside the existing legal system. Thus, anything stipulated within the legal system becomes the object of knowledge at law school. ${ }^{76}$

Law, Legal Pluralism and The Customary Community Movement"] in Satjipto Rahardjo dan Hukum Progresif: Urgensi dan Kritik [Satjipto Rahardjo and Progressive Law: Urgency and Critique], edited by Myrna Safitri, Awaluddin Marwan and Yance Arizona (Jakarta: Epistema-Huma, 2011), pp. 263-277.

${ }^{74}$ For a simple overview of Antonio Gramsci's thinking see Franz Magnis-Suseno, Dalam Bayangan Lenin: Enam Pemikir Marxisme dari Lenin sampai Tan Malaka [In Lenin's Shadow: Six Thinkers of Marxism from Lenin to Tan Malaka], (Jakarta: Gramedia Pustaka Utama, 2003), pp. 171-204.

${ }^{75}$ A proper explanation concerning this subject is provided by Roberto Mangabeira Unger, "The Critical Legal Studies Movement," Harvard Law Review Vol. 96 No. 3 (January 1983): 561-675.

${ }^{76}$ On the positive legal system being the object of the science of law see in Bernard Arief Sidharta, Refleksi tentang Struktur Ilmu Hukum: Sebuah Penelitian tentang Fundasi Kefilsafatan dan Sifat Keilmuan Ilmu Hukum sebagai Landasan Pengembangan Ilmu Hukum Nasional Indonesia [Reflection on the Structure of the Science of Law: A Research on the Philosophical Foundation and Scientific Nature of the Science of Law as a Basis for the Development of Indonesia's National Legal Science], (Bandung: CV Mandar Maju, 2000), 
Accordingly, the object of Critical Legal Studies' attention becomes relevant. The epistemology of positivist law brings a complexity of consequences for every legal expert, including Utrecht. Utrecht ultimately became the ideological "mouth" of the ruling class which had an interest in the Indonesian legal system at the time, whilst he possessed a critical reflection taking sides with the interest of the people at large, particularly customary law communities. This was in spite of the fact that the legal norms of positive law which were applicable at the time did not necessarily reflect the interests of the people at large.

Notwithstanding Utrecht's above described inconsistency, his proposition of a law with the character of pengayoman (guardianship) reflecting the idea of Pancasila characterized by gotong royong (mutual cooperation) is a highly interesting subject of critical reflection. Whether or not his proposition is acceptable is beside the point; such ideal has become almost entirely extinct nowadays, particularly in the process of law enforcement. Actors both within as well as outside the power structure are constantly crossing disputes using well-sounding words based on one argument: "law enforcement may not be politicized". On the face of it, the argument appears to be objective and neutral, capable of creating the sense that law is just and impartial. However, unfortunately, in reality it only creates an ambience of "vengeance" among various parties.

Conflicts among institutions of power, such as the Komisi Pemberantasan Korupsi (KPK) (Anti-Corruption Commission) and Polri (the National Police) in the case of nominating Budi Gunawan as the Chief of Police, tend to position law as the rule of the game in a boxing ring. Each of the parties keep on relentlessly defending or blaming KPK and Polri respectively, even though the President of this Republic, Joko Widodo himself has been making statements asking to halt these counterproductive disputes. They still continue to demonstrate the law of "vengeance" using existing legal instruments to attack each other until their enemy lies defeated. ${ }^{77}$ At the same time, some of the elite or a majority of the Indonesian public are also captivated by the adagiums thrown out by actors hungry for power, including legal experts "wallowing" in this fighting arena as advocates guardians of power; "for the sake of legal certainty", "it must be based on the presumption of innocence", "it must be in compliance with the procedure and mechanism of law", "for the sake of justice" and others, ultimately causing the law to appear helpless, subsequently leading to the fragmentation of the elements of society and power resulting in a sense of social frustration; for instance, such an anomic situation would not have occurred if A was president, or party B should have been elected, or they are all just the same, and so on and so forth.

When justice is perceived as being increasingly distant, the sense of certainty of law also becomes vague, which means that law enforcement in Indonesia has failed to provide protection (pengayoman - guardianship) to its citizens, while in fact pengayoman (guardianship) is every citizen's most authentic expectation of their country. However, it needs to be admitted that the spirit (soul) of pengayoman

pp. $131-135$.

77 Even though it has been considered as "finished", the settlement does not at all reflect the spirit of pengayoman (guardianship or protection). The dispute between KPK and Polri has been settled by bartering cases. Cases investigated by KPK have been transferred to the Attorney General's Office. Following that, Polri halted the legal process against KPK's leadership and staff. This kind of settlement has invited protest both from within as well as outside KPK. For this subject, see in Rusman Paraqbueq and Linda Trianita, "Opsi Kalah dari Lantai Tiga" ["The Option of Losing from the Third Floor"], Majalah Berita Mingguan Tempo (9-15 March 2015): 44-46. 
(guardianship) as the objective of law proposed by Utrecht, already rests in peace nowadays -or it may have become an antique word in a museum or a librarybecause unlike the aforementioned formalistic-procedural adagiums, pengayoman (guardianship) does not seem to have an appeal to actors hungry for power.

Once again, with his above described political contribution and role, Utrecht is undoubtedly one of Indonesia's best legal scholars. Nowadays, it is hard to come by a highly intelligent legal scholar like him, who writes readily and efficiently about contemporary legal politics with an ideological intonation, almost like a "spokesperson" of legal politics.

Even the few legal scholars of today who try to write about contemporary legal politics do not use heavy ideological jargon, despite political slogans such as "Mental Revolution", "Trisakti" and "Nawacita" being frequently used by people in power. Such political slogans, particularly the ones using the term "revolution" and "Trisakti" call for a more in-depth elaboration, considering that both of these political terms carry an ideological nuance.

It may well be that ideology has become an ancient item in today's world, having lost its appeal to legal scholars. Similarly, little interest is being attributed to customary criminal law nowadays; there tends to be more focus on the obsession surrounding -the ongoing and never ending- project of criminal law codification. This is an unavoidable historical implication, considering that ever since President Soeharto's government, the discourse on law, particularly of ideological nature, has been practically non-existent.

\section{Conclusion}

Based on the foregoing, it is obvious that Utrecht truly deserves to be regarded as the best legal scholar that Indonesia has ever had. His intellectual proposal about pengayoman (guardianship) as the purpose of law needs to be revisited, and it can potentially become an oasis in contemporary law enforcement which is perceived as becoming increasingly uncivilized.

His belief in public interest under the law also remains relevant, particularly in the context of criminal law which has been filled with "shows" lately, causing concern as little and helpless people are being brought to justice for trivial cases. It is both timely and appropriate to reconsider customary criminal law which emphasizes harmony as opposed to vengeance. Accordingly, it is highly appropriate and necessary to revitalize Utrecht's ideals about Indonesian law characterized by Pancasila and gotong royong (mutual help).

\section{Bibliography}

\section{Books}

Apeldoorn, L. J. van. Inleiding tot de Studie van het Nederlandse Recht, atau Pengantar Ilmu Hukum [Inleiding tot de Studie van het Nederlandse Recht, or An Introduction to the Science of Law]. 23rd print. Translated by Oetarid Sadino. Jakarta: Pradnya Paramita, 1986.

Bahar, Saafroedin, Ananda B. Kusuma and Nannie Hudawati. Risalah Sidang Badan Penyelidik Usaha-Usaha Persiapan Kemerdekaan Indonesia (BPUPKI) - Panitia Persiapan Kemerdekaan Indonesia (PPKI) [Proceedings of the Session of The Investigating Committee for the Preparation of Indonesian Independence Preparatory Committee for Indonesian Independence] Jakarta: Sekretariat 
Negara Republik Indonesia, 1995.

Beccaria, Cesare. Of Crimes and Punishment. New York: Marsilio Publishers, 1996.

Bemmelen, J. M. van. Ons Strafrecht 1: Het materiele strafrecht algemen deel [Criminal Law 1: Criminal Law Material General Part]. Translated by Hasnan. Bandung: Binacipta, 1987.

Boot, Machteld. Nullum Crimen Sine Lege and the Subject Matter Jurisdiction of the International Criminal Court: Genocide, Crimes Against Humanity, War Crimes. School of Human Rights Series, Volume 12. Antwerpen: Intersentia.

Copleston, Frederick. A History of Philosophy Volume V: Modern Philosophy: The British Philosophers from Hobbes to Hume. New York: Doubleday, 1959.

Eatwell, Roger. "Ideologies: Approaches and Trends." In Contemporary Political Ideologies. Edited by Roger Eatwell and Anthony Wright (Boulder, San Fransisco: Westview Press, 1993).

Feith, Herbert \& Castles, Lance. Indonesian Political Thinking 1945-1965. Jakarta: Equinoxx Publishing, 2007.

Freeman, M. D. A. Llyod's Introduction to Jurisprudence, sixth edition. London: Sweet \& Maxwell Ltd, 1994.

Huijbers, Theo. Filsafat Hukum [The Philosophy of Law]. 3rd print. Yogyakarta: Penerbit Kanisius, 1995.

Kartanegara, Satochid. Hukum Pidana: Kumpulan Kuliah [Criminal Law: A Collection of Lectures]. Balai Lektur Mahasiswa.

Kelsen, Hans. The Pure Theory of Law. California: University of California P r e s s , 1967.

Magnis-Suseno, Franz. Dalam Bayangan Lenin: Enam Pemikir Marxisme dari Lenin sampai Tan Malaka [In Lenin's Shadow: Six Thinkers of Marxism from Lenin to Tan Malaka]. Jakarta: Gramedia Pustaka Utama, 2003.

Mehern, Arthur T. von "Paul Johan Anselm von Feurbach." In Encylopedia Americana Volume 11. Connecticut: Grolier Incorporated, 1983.

Montesquieu, Charles de Secondat Baron de. The Spirit of Laws. New York: Prometheus Books, 2002.

Nasution, Adnan Buyung. The Aspiration for Constitutional Government in Indonesia: A Socio-legal Study of the Indonesian Konstituante 1956-1959. Jakarta: Pustaka Sinar Harapan, 1992.

Poespowardojo, Soerjanto. "Pancasila Sebagai Ideologi Ditinjau Dari Segi Pandangan Hidup Bersama” ["Pancasila As An Ideology Viewed from the Aspect of Living In A Community"]. In Pancasila Sebagai Ideologi dalam Berbagai Bidang Kehidupan Bermasyarakat, Berbangsa dan Bernegara [Pancasila As Ideology in Various Areas of Life As Society, Nation and State]. Edited by Oetojo Oesman and Alfian. Jakarta: BP-7 Pusat, 1991.

Remmelink, Jan. Hukum Pidana: Komentar atas Pasal- Pasal Terpenting dari Kitab Undang-Undang Hukum Pidana dan Padanannya dalam Kitab Undang-Undang Hukum Pidana Indonesia [Criminal Law: Commentary on the Most Important Articles of the Criminal Law and Concordance with the Indonesian Criminal Code]. Translated by Tristam Pascal Moeliono, et al. Jakarta: Gramedia Pustaka Utama, 2003.

Rocamora, J. Elisio. Nasionalisme Mencari Ideologi: Bangkit dan Runtuhnya PNI, 19461965 [Nationalism in Search of Ideology: The Rise and Fall of the Indonesian Nationalist Party, 1946-1965]. Translated by Daniel Dhakidae. Jakarta: Pustaka Utama Grafiti, 1991. 
Sidharta, Bernard Arief. Refleksi tentang Struktur Ilmu Hukum: Sebuah Penelitian tentang Fundasi Kefilsafatan dan Sifat Keilmuan Ilmu Hukum sebagai Landasan Pengembangan Ilmu Hukum Nasional Indonesia [Reflection on the Structure of the Science of Law: A Research on the Philosophical Foundation and Scientific Nature of the Science of Law as a Basis for the Development of Indonesia's National Legal Science]. Bandung: CV Mandar Maju, 2000.

Simanjuntak, Marsillam. Pandangan Negara Integralistik: Sumber, Unsur, dan Riwayatnya dalam Persiapan UUD 1945 [An Integralistic View of the State: Its Sources, Elements and History in the Preparation of the 1945 Constitution]. Jakarta: Pustaka Utama Grafiti, 1994.

Soesilo, R. Pokok-Pokok Hukum Pidana, Peraturan Umum dan Delik- Delik Khusus [Fundamentals of Criminal Law, General Provisions and Special Offense]. Bogor: Politea, 1984.

Steni, Bernadinus. "Hukum Progresif, Pluralisme Hukum dan Gerakan Masyarakat Adat" ["Progressive Law, Legal Pluralism and The Customary Community Movement"]. In Satjipto Rahardjo dan Hukum Progresif: Urgensi dan Kritik [Satjipto Rahardjo and Progressive Law: Urgency and Critique]. Edited by Myrna Safitri, Awaluddin Marwan and Yance Arizona. Jakarta: Epistema-Huma, 2011.

Sukarno. "Marhaen, A Symbol of the Power of the Indonesian People." In Indonesian Political Thinking 1945-1965. Edited by Herber Feith and Lance Castles. Jakarta: Equinox Publishing, 2007.

Tebbit, Mark. Philosophy of Law: An Introduction. London: Routledge, 2005.

Utrecht, E. "Hukum Pidana jang tidak Tertulis (Ongeschereven Strafrecht)" ["Unwritten Criminal Law"]. In Buku Peringatan Dies Natalis Ke-VI Senaat Mahasiswa Fakultas Hukum dan Pengetahuan Masjarakat Universitas Indonesia [Year Book Dies Natalis VI of the Students' Senate of the Faculty of Law and Social Science Universitas Indonesia]. Jakarta: Senaat Mahasiswa Fakultas Hukum dan Pengetahuan Masjarakat Universitas Indonesia, 1956.

Utrecht, E. Hukum Pidana I: Suatu Pengantar Hukum Pidana untuk Tingkat Pelajaran Sarjana Muda Hukum, Suatu Pembahasan Pelajaran Umum. [Criminal Law I: An Introduction to Criminal Law for Undergraduate Studies, A General Discussion].

Utrecht, E. Hukum Pidana II: Suatu Pengantar Hukum Pidana untuk Tingkat Pelajaran Sarjana Muda Hukum, Suatu Pembahasan Pelajaran Umum. [Criminal Law II: An Introduction to Criminal Law for Undergraduate Studies, A General Discussion].

Utrecht, E. and Moh. Saleh Djindang. Pengantar dalam Hukum Indonesia [An Introduction to Indonesian Law]. 11th print. Jakarta: Penerbit Ichtiar Baru and Penerbit Sinar Harapan, 1989.

Utrecht, E. and Moh. Saleh Djindang. Pengantar Hukum Administrasi Negara Indonesia, [An Introduction to Indonesian State Administrative Law]. 8th print. Jakarta: Ichtiar Baru, 1985.

Utrecht, Elien. Melintasi Dua Jaman: Kenangan tentang Indonesia Sebelum dan Sesudah Kemerdekaan [Across Two Eras: Memories of Indonesia Before and After Independence]. Translated by Achmad Sunjayadi. Depok: Komunitas Bambu, 2006.

Ratnapala, Suri. Jurisprudence. Cambridge: Cambridge University Press, 2009.

Rousseau, Jean-Jacques. The Social Contract. London: Penguin Books, 1968.

Qvortrup, Mads. The Political Philosophy of Jean-Jacques Rousseau: The

Impossibility of Reason. Manchester: Manchester University Press, 2003. 


\section{Articles}

Attamimi, A. Hamid S. "Peranan Keputusan Presiden Republik Indonesia Dalam Penyelenggaraan Pemerintahan Negara: Suatu Studi Analisis Mengenai Keputusan Presiden Yang Berfungsi Pengaturan Dalam Kurun Waktu Pelita I Pelita IV" ["The Role of the Decree of the President of the Republic of Indonesia In State Administration: A Study on the Analysis of Presidential Decree Functioning as Regulation During the Period of Ist Five Year Development Plan"]. Dissertation to Attain the Title Doktor Dalam Ilmu Hukum, Universitas Indonesia, Jakarta, 12 December 1990.

Gunawan, Andrew H. "Honor to a Friend, Bambang Kusnohadi." Indonesia Volume 16 (1973): 149-152.

Manullang, E. Fernando M. “Negara dan Pancasila: Refleksi Kritis Atas Gagasan Hukum Padmo Wahjono" ["The State and Pancasila: A Critical Reflection On the Legal Ideas of Padmo Wahjono"]. Jurnal Hukum Jentera Ed. 15 Year IV (January-March 2007): 134-135.

Manullang, E. Fernando M. "Refleksi Terhadap Dilema G. J. Resink" [“A Reflection on G.J. Resink's Dilemma"]. In "The Significance of the History of International Law in Indonesia." Jurnal Hukum Jentera Ed. 18 (January-June 2008): 112-136.

Paraqbueq, Rusman and Linda Trianita. "Opsi Kalah dari Lantai Tiga" ["The Option of Losing From the Third Floor"]. Majalah Berita Mingguan Tempo (9-15 March 2015): 44-46.

Robinson, Geoffrey B. "The Economic Foundations of Political Conflict in Bali, 1950 1965." Indonesia Volume 54 (1992): 59-94.

Sastrapratedja, M. "Pancasila Sebagai Dasar Negara, Asas Etika Politik dan Acuan Kritik Ideologi" ["Pancasila As Foundation of the State, the Principle of Political Ethics and Reference in Ideological Critique"]. In Proceeding Kongres Pancasila: Pancasila Dalam Berbagai Perspektif [Pancasila Congress: Pancasila In Various Perspectives]. Edited by Moh. Mahfud MD et. al. Jakarta: Sekretariat Jenderal Mahkamah Konstitusi, 2009.

Unger, Roberto Mangabeira. "The Critical Legal Studies Movement." Harvard Law Review Vol. 96 No. 3 (January 1983): 561-675.

\section{Websites}

Hukum Online. "Studium Generale Mr. Utrecht di Unhas.” http://www.hukumonline. com/berita/baca/lt4f66e9aef0793/istudium-generale-i-mr-utrecht-di-unhas. Accessed on 14 February 2014.

Kahin, George McT. "In Memoriam Harry J. Benda." http://www.yale.edu/seas/ Benda obit.pdf. Accessed on 14 March 2015. 